\title{
Non-protein nitrogen compound poisoning in cattle
}

\author{
Amir Hossan Shaikat, Mohammad Mahmudul Hassan, S. K. M. Azizul Islam, Shahneaz Ali Khan, Md. Ahasanul \\ Hoque, Md. Nurul Islam and Mohammad Belayet Hossain, Department of Physiology, Biochemistry and \\ Pharmacology, Chittagong Veterinary and Animal Sciences University
}

\begin{abstract}
The study was carried out in Chittagong Veterinary and Animal Sciences University (CVASU), Chittagong to find out the causes of sudden death of cattle in the Military Dairy Farm, Chittagong. To explore the cause of death, clinical history, clinical signs were recorded. Finally, postmortem was done and samples were collected for laboratory diagnosis. The ruminal $\mathrm{pH}$ was 9.0 and the clinical history along with signs suggests possible non-protein nitrogenous compound poisoning. The laboratory diagnosis coincides with nitrate poisoning which focuses possible relationship between non-protein nitrogenous compound and nitrate poisoning. The study recommends maintaining proper cautions to use urea in concentrate feed.
\end{abstract}

Key words : Non-protein, urea, ammonia, nitrate, poison

\section{Introduction}

Urea poisoning is one of the common toxicities found in ruminants especially cattle. It is used as an alternative nonprotein nitrogen (NPN) source in ruminant diet and its nitrogen is liberated as ammonia in rumen and then the released ammonia is used by rumen microbes to synthesize their own protein. But in urea, nitrogen can be replaced by up to $16 \%$ of the dietary nitrogen along with 2 or more feeds for dairy cows (Froslie, 1977). Dietary urea has been used for decades as an effective and inexpensive source of nitrogen for ruminal microbial utilization. It is rapidly hydrolyzed upon entry into the rumen resulting in peak rumen ammonia concentrations within the first hour of consumption. However, ammonia that is not utilized for microbial synthesis is absorbed across the gastrointestinal tract, with increasing ruminal ammonia concentrations resulting in increased rate of absorption (Huntington, 1986). Increased blood ammonia concentrations alter hepatic metabolism by increasing ureagenesis may also affect glucose metabolism in the liver and peripheral tissues (Huntington et al., 2006). Poisoning may occur periodically when ruminants gain access to large quantities or are fed large amounts of urea; when they are not adapted to it or when feeds are improperly mixed or high urea concentration is present in low energy, low protein, and high roughage diets (Ortolani et al., 2000). In Bangladesh, urea is also used in urea molasses straw preparation and/or sometimes only urea is supplemented with cattle feed more frequently in beef fattening programme or in dairy production. The present study was, therefore, focused on the
NPN poisoning in Military Dairy Farm, Chittagong to find out the cause behind death of some cattle in their shed.

\section{Materials and Methods}

The authority of Military Dairy Farm, Chittagong reported that sudden death of some cattle occurred after concentrate feeding. Based on the complain, the Toxicology Laboratory of Chittagong Veterinary and Animal Sciences University (CVASU) collected feed, water and molasses samples from that mentioned farm. The whole study was conducted based on direct interview of the farm's staff, postmortem examination of the dead animals and laboratory diagnosis.

Description of the farm: The Military Dairy Farm is located in a hilly area of the Chittagong Cantonment, Baluchara, Chittagong. There is a total of 8 sheds for cattle with available cultivable land for fodder. All cattles were crossbreed between 1.5-2 years of age.

Case history: The cattle were regularly fed with fodder along with concentrated feeds. On the day of case fatality, the caretaker of the farm reported that cattle in the affected shed out 8 sheds, cattle were offered concentrated feed mixed with a new pack of molasses at $3 \mathrm{pm}$. The new pack of molasses was carried in the same vehicle as for urea and one sack of urea fertilizer was found opened. After almost 40 minutes of feeding, the cattle were found with labored breathing, mydriasis, salivation, convulsion, bloat and increased body temperature between $104^{\circ}-105^{\circ} \mathrm{F}$. Among 24 cattle of affected shed, 19 (male=2, female=17) cattle showed clinical sign and within 2-3 hours of onset of clinical sign 17 cattle were dead. 
Treatment given: After the onset of clinical signs the animals of the case shed were treated with $1 \%$ methylene blue@20 mg/kg body weight introvenously, vinegar @ 2L orally, 5\% Dextrose saline@ @1000ml, atropine sulphate @ $0.25 \mathrm{mg} /$ body weight intramuscularly. Trocarizations of some animals were done by trocar and canula and carminative mixture (No Bloat $^{\circledR} \quad$ suspension-Square Pharmaceuticals Bangladesh) was given. Later, StreptomycinPenicillin combination (SP-vet ${ }^{\circledR}$-Acme Pharmaceuticals Bangladesh) was administered intramuscularly.

Post-mortem inspection: Postmortem examinations of dead cattle were performed and various organ lesions were noted.

Laboratory tests: The various organs from dead animals and feed samples were collected by the personnel of the Military Dairy Farm. Samples were packed properly within sterile zipper clip bag and submitted to the Toxicology Laboratory, CVASU. Two blood samples were also given to the Physiology Laboratory for hemoglobin level analysis. After taking the $\mathrm{pH}$ of rumen content by Hanna pH meter (Hanna instruments, USA) toxicological testing was done according to joint reaction (Sandhu, 1999).

\section{Results}

The young are less affected (13\%) whereas the adult are more affected (67\%) as shown in Table1. Besides that, Male were less prone to be affected (8\%) with less case fatality (5\%) in comparison to highly affected female (72\%) with high case fatality (84\%).

On postmortem examination congested liver and kidney, frothy bloat in rumen, gastroenteritis with hemorrhagic intestine, edema of lung were observed. Toxicological testing was done on the supplied samples according to Sandhu (1999) and Nitrate and Nitrite (Ammonia) positive reactions were found in some samples.

Table-1: Attack rate and case fatality according to animals

\begin{tabular}{|c|c|c|c|c|c|c|c|c|}
\hline \multirow[t]{2}{*}{ Factor } & \multirow[t]{2}{*}{ Category } & \multirow[t]{2}{*}{ Total $(\mathrm{N}=24)$} & \multirow{2}{*}{$\begin{array}{c}\text { Affected } \\
\text { animals } \\
(\mathrm{N}=19)\end{array}$} & \multirow{2}{*}{$\begin{array}{l}\text { Death } \\
(\mathrm{N}=17)\end{array}$} & \multicolumn{2}{|c|}{ Attack rate } & \multicolumn{2}{|c|}{ Case fatality } \\
\hline & & & & & Overall & $\begin{array}{l}\text { According } \\
\text { to factor }\end{array}$ & Overall & $\begin{array}{l}\text { According to } \\
\text { factor }\end{array}$ \\
\hline \multirow[t]{2}{*}{ Age (Years) } & 1.5 & 3 & 3 & 1 & $3 / 24=0.13$ & $3 / 3=1$ & $1 / 19=0.05$ & $1 / 3=0.33$ \\
\hline & 2.0 & 21 & 16 & 16 & $16 / 24=0.67$ & $16 / 21=0.76$ & $16 / 19=0.84$ & $16 / 16=1$ \\
\hline \multirow[t]{2}{*}{ Sex } & Male & 2 & 2 & 1 & $2 / 24=0.08$ & $2 / 2=1$ & $1 / 19=0.05$ & $1 / 2=0.5$ \\
\hline & Female & 22 & 17 & 16 & $17 / 24=0.72$ & $17 / 22=0.77$ & $16 / 19=0.84$ & $16 / 17=0.94$ \\
\hline
\end{tabular}

Table-2: Test results of supplied samples

\begin{tabular}{lc}
\hline \multicolumn{1}{c}{ Type of samples (Total number) } & Ammonia test \\
\hline Rumen content (2) & + \\
Liver (2) & - \\
Kidney (2) & - \\
Molasses (1) & + \\
Concentrate feed with molasses & + \\
$(1)$ & - \\
Concentrate feed without & \\
molasses (1) & - \\
Supplied water (1) & \\
\hline
\end{tabular}

Blood samples were analyzed at Physiology Laboratory, CVASU and average hemoglobin level was found $5.35 \pm 0.2 \mathrm{gm} / \mathrm{dl}$. The $\mathrm{pH}$ of rumen fluid was determined and was found 9.0.

\section{Discussion}

Non-feed commodities were commonly found in the farm that can create nitrate toxicity problems. Ammonium nitrate and urea fertilizers, have been implicated in poisoning cases. As cattle graze pastures, or forage around buildings, they will locate fertilizer spills and quickly consume the material. When urea fertilizer is consumed, the urea molecule is broken down into two ammonia units. Rumen and blood ammonia levels increase dramatically within 20-30 minutes of consumption (Mathew, 1989). Blood ammonia concentrations generally cause the toxicity problems with symptoms of ammonia poisoning in animals are sunken eyes and loss of elasticity of the skin due to dehydration, high temperature, laboured respiration, muscle tremors or tetany and a fluid 
filled rumen of $p \mathrm{H}$ of $8-9$ (Bartley et al., 1976) which coincides with our findings. Mydriasis occurs in parasympatholytic status or a sympathetic stimulation (Mathew, 1989). The presence of signs such as mydriasis and tachycardia suggests that ammonia poisoning could elicit a sympathetic or a parasympatholytic status. This hypothesis contradicts with Haliburton and Morgan (1989) statement that during ammonia poisoning the parasympathomimetic status predominates and could be responsible for signs such as bradycardia and profuse salivation. The presence of congestion of liver with some damage matched with findings Horner (1982) who reported liver congestion and pericarditis. It is generally agreed that urea toxicity is equivalent to ammonia poisoning (Shirley, 1986). Ammonia toxicity prevents the release of carbon dioxide from the red blood cells while nitrites prevent the red blood cells from carrying oxygen to body tissue. Some cattle survived after treating with vinegar. The antidote for a mature cow suffering from ammonia toxicity is the oral administration of $4 \mathrm{~L}$ vinegar and this may need to be repeated every 20-30 minutes until the symptoms disappear (Horner, 1982). Toxicity problems are not usually associated with the ingestion of protein but rather with ingestion of excess levels of urea. The utilization of ammonia depends upon the growth rate of ruminal microbes and is usually limited by the availability of readily fermentable carbohydrates (i.e. grains). After an animal consumes feed that contains nitrate, rumen ammonia levels may increase significantly and it is unusual to have blood ammonia levels increased (Kemp, 1977). Healthy animals have normal methemoglobin levels that are relatively constant at $2-3 \%$ of total hemoglobin. When high nitrate feeds are consumed, moderate nitrate poisoning symptoms appear and $20-40 \%$ of the hemoglobin is converted to methemoglobin (Johnson, 1983; Pfister, 1988) and severe symptoms or death can occur when blood methemoglobin levels rise up to 67-90\% (Asbury and Rhode, 1964). Veterinarians have various drugs and antidotes that can be given to animals to relieve from acute poisoning symptoms. Chronic cases are not cured by the administration of these products (Page, 1987). Methylene Blue is able to convert methemoglobin back to hemoglobin. The dosage must be within a specified narrow range otherwise it can intensify the problem. Intravenous injection of methylene blue in saline solution (4\%) for horses must be in the $1-2 \mathrm{mg} / \mathrm{kg}$ range while cattle and sheep require $20 \mathrm{mg} / \mathrm{kg}$ to obtain satisfactory results (Blood et al., 1989).

\section{Conclusion}

Nonprotein nitrogenous sources such as urea has benn used as feed additive for a long time in cattle feeding. The conventional and proper dose maintaining in mixing of urea with feed can be a handy and economic source of protein from nonprotein nitrogenous substances for animals. The deliberate use of urea in cattle feed can be fatal and cause severe farm animal loss. So, farmers should have proper knowledge about the dose and method of urea supplementation in cattle feed and should be cautious enough in this situation.

\section{References}

Asbury, A.C. \& Rhode E.A. 1964. Nitrate Intoxication in Cattle: The Effects of Lethal Doses of Nitrite on Blood Pressure. Am J. Vet Res. 25: 1010-1017.

Bartley, E.E., Davidovich, A.D., Barr, G.W., Griffel, G.W., Dayton, A.D., Deyoe, C.W. \& Bechtle RM. 1976. Ammonia Toxicity in Cattle. Rumen and Blood Changes Associated with Toxicity and Treatment Methods. J. Anim. Sci. 43:835-841.

Blood, D.C., Henderson, J.A., Radostits, O.M., Arundel, J.H. \& Gay, C.C. 1989. Veterinary

Medicine: a textbook of the diseases of cattle, sheep, pigs and horses. 5th edn. pp.1135, Balliere Tindall, London.

Froslie, A. 1977. Feed-related urea poisoning in ruminants. Folia Veterinaria Latina. 7(1): 17-37

Haliburton, J.C. \& Morgan, S.E. 1989. Nonprotein nitrogeninduced ammonia toxicosis and ammoniated feed toxicity syndrome. Vet. Clin. North Am. Food Anim. Pract. 5(2): 237-49.

Horner, R. F. 1982. Suspected Ammonium Fertilizer Poisoning in Cattle. Vet. Rec. 110: 472-474.

Huntington, G.B. 1986. Uptake and transport of nonprotein nitrogen by the ruminant gut. Fed. Proc. 45:2272-2276.

Huntington, G. B., Harmon, D. L., Kristensen, N. B., Hanson, K. C. \& Spears, J. W. 2006. Effects of a slow-release urea source on absorption of ammonia and endogenous production of urea by cattle. Anim. Feed Sci. Technol. 130:225-241.

Johnson, J. L., Schneiderm, N. R., Kelling, C. L., Doster, A. R. 1983. Nitrate Exposure in perinatal Beef Calves. Am. Assoc. Vet. Lab Diagnosticians., pp $167-180.30^{\text {th }}$ Proceedings. 
Kemp, A., Geurink, J. H., Haalstra, R. T. and Malestein, A. 1977. Nitrate Poisoning in Cattle: Changes in Nitrate in Rumen Fluid and Methaemoglobin Formation in Blood After High Nitrate Intake. Neth. J. Agric. Sci. 25:51-62.

Mathew, I. G. 1989. Large Animal Neurology: a handbook for veterinary clinicians. pp 380, Philadelphia: Lea \& Febiger.

Ortolani, E. I., Mori, C. S., Filho, J. A. R. 2000. Ammonia toxicity from urea in a Brazilian dairy goat flock. Veter. and Human Toxico. 42(2): 87-89.

Page, R. 1987. High Nitrate Levels Cause Reproductive Problems. Hoard's Dairyman, pp 635.
Pfister, J. A.1988. Nitrate intoxication of ruminant livestock. In: (James, LF, Ralphs MH, and Nielson, eds.), The Ecology and Economic Impact of Poisonous Plants on Livestock Production, pp-233-260, Westview Press, Boulder, CO.

Sandhu, H. S. 1999. Laboratory Manual on Veterinary Pharmacology and Toxicology, $1^{\text {st }}$ edn. pp 255 , Kalyani Publishers, India.

Shirley, R.L. 1986. Nitrogen and Energy Nutrition of Ruminants, $2^{\text {nd }}$ edn. pp-244, Academic Press 